\title{
AVALIAC̣ÃO CLÍNICA E EPIDEMIOLÓGICA DO PAPILOMAVIRUS HUMANO EM MULHERES IDOSAS EM UNIDADES DE SAÚDE EM BELÉM - PARÁ - BRASIL
}

\author{
Wiviane Maria Torres de Matos Freitas \\ Orientadora: Hellen Thais Fuzii \\ Programa de Pós-Graduação em Doenças Tropicais \\ Universidade Federal do Pará
}

\begin{abstract}
Introdução: $O$ envelhecimento é um fenômeno real que traz modificações individuais e sociais. Destaca-se que, na atualidade, a população idosa tem permanecido atuante no campo de atividade sexual. Outrora esse evento era particular aos jovens, hoje os idosos, além de serem sexualmente ativos, ainda se expõem cada vez mais às doenças sexualmente transmissíveis (DST), incluindo a infecção pelo $\mathrm{Pa}$ pilomavírus Humano - HPV, em virtude de não adotarem hábitos seguros como o uso do preservativo.

Objetivo: $O$ presente estudo teve por objetivo avaliar clínica e epidemiologicamente a presença do HPV em mulheres idosas de unidades de saúde em Belém/PA. Metodologia: Trata-se de um estudo transversal, descritivo, analítico e quantitativo. As informações foram coletadas por meio de questionário clínico e epidemiológico contendo variáveis sobre coitarca, parceiros sexuais, hábitos de etilismo e tabagismo etc. Foram coletadas células da cérvix uterina para realização de colpocitologia oncótica, extração de DNA e detecção de DNA do HPV. A detecção do HPV foi realizada por técnica de PCR; e para subtipagem, a de PCR em tempo real. As coletas se deram após aprovação do Comitê de Ética em Pesquisa do Núcleo de Medicina Tropical/UFPA sob o parecer $n^{\circ} 401.991$ e analisadas por meio da construção do banco de dados, e aplicados os testes Qui-quadrado e Exato de Fisher com nível de significância admitido de $\alpha \leq 0,05$. Resultados: Para
\end{abstract}

análise dos resultados, contou-se com 159 amostras de idosas, em média de 67,98 anos de idade, em maioria viúvas e com ensino fundamental incompleto. Registrou-se uma prevalência de $6,28 \%$ de infecção por HPV nessas idosas pesquisadas. Observou-se uma importante relação da infecção com a multiplicidade de parceiros $(p \leq 0,006)$ e com o hábito de tabagismo durante a vida $(p \leq 0,03)$. Outro fato importante para a presença do vírus é com relação às idosas que permanecem em atividade sexual, pois apresentaram maior prevalência de HPV $(14,28 \%)$ do que as sem atividade $(2,72 \%)$. Acrescenta-se o evento registrado, de uma idosa pesquisada, de infecção por um subtipo de alto risco oncológico (HPV16). Cabe ressaltar que todas as idosas do estudo receberam o resultado das análises citológicas dentro dos padrões de normalidade. Conclusões: Conclui-se que apesar da prevalência se apresentar decrescente nessa faixa etária, as idosas estão expostas a fatores de risco que podem contribuir para o aumento nas futuras taxas de câncer do colo do útero, em particular por receberem o resultado do exame citológico dentro dos padrões de normalidade. Dessa maneira, destaca-se a importância desta pesquisa e da necessidade de permanecer com o constante rastreio em mulheres de todas as idades nas diversas unidades de saúde. Palavras-chave: Papilomavírus Humano; Câncer de Colo Uterino; Idoso; Prevalência. 